\title{
POSTED WORK AND OCCUPATIONAL SAFETY AND HEALTH: A LITERATURE REVIEW
}

\author{
Sonila DANAJ
}

COBISS 1.02

\section{ABSTRACT \\ Posted Work and Occupational Safety and Health: A Literature Review}

This article provides a review of the literature on posting and occupational safety and health (OSH). Although the vulnerabilities of posted workers are discussed in the literature on posting, and the overall OSH risk factors, including those relevant to migrant workers, are discussed in the literature on $\mathrm{OSH}$, the two strands of literature barely intersect. There is therefore an immediate need to study the occupational safety and health of posted workers throughout the European Union. Social factors influencing OSH risks, such as employment fragmentation and precarity, and the various forms of cross-border labour mobility, such as posting, should also be further explored.

KEY WORDS: posted work, European Union, occupational safety and health, literature review

\section{IZVLEČEK}

\section{Napoteno delo ter varnost in zdravje pri delu: Pregled literature}

Članek prinaša pregled literature s področja napotenih delavcev ter varnosti in zdravja pri delu (VZD). Čeprav ranljivi položaj napotenih delavcev obravnava literatura o napotitvah, splošne dejavnike tveganja VZD, vključno s tistimi o migrantskih delavcih, pa literatura o varnosti in zdravju pri delu, se oba segmenta komajda prekrivata. Prav zato se pojavlja potreba po proučitvi poklicne varnosti in zdravja napotenih delavcev v celotni Evropski uniji. Podrobneje bi morali raziskati tudi tiste socialne dejavnike, ki vplivajo na zdravje in varnost pri delu, kot so zaposlitvena razdrobljenost in prekarnost ter različne oblike čezmejne zaposlitvene mobilnosti, med katere sodijo napotitve delavcev.

KLJUČNE BESEDE: napoteno delo, Evropska unija, varnost in zdravje pri delu, pregled literature

Ph.D. Candidate in Sociology, Researcher, European Centre for Social Welfare Policy and Research, Berggasse 17, A-1090 Vienna; danaj@euro.centre.org 


\section{INTRODUCTION}

The Posting of Workers Directive (96/71/EC) (PWD) introduced in 1996 aimed to regulate temporary labour mobility in the common European market. The numbers of postings increased after the EU enlargement of 2004, particularly from the lower-income member states of Central and Eastern Europe to the higher-income member states. Although accurate data on posted workers are difficult to obtain because of the differences in recording and reporting their mobility among EU member states, the closest estimates are drawn from the number of portable document A1 forms (PDs A1s) issued by sending and receiving countries. Recent data from the European Commission indicate an overall increase in the number of PD A1s issued from approximately 1 million workers in 2010 to 1.5 million workers being posted from one EU member state to another in 2015. However, these figures do not differentiate between the total number of individual posted workers and the number of postings, and it has been estimated that the number of unique posted workers is substantially lower and lies at around 60 percent of the total of PD A1s (Pacolet, De Wispelaere 2016). Because of its temporary nature, posting is particularly used in low value chain sectors that cannot be delocalized, such as construction, services and agriculture, which has resulted in a substantial part of posting in these sectors, with construction accounting for nearly half of the overall number of incoming and outgoing postings. Skills shortages have also triggered the mobility of highly-skilled workers, in particular in sectors such as engineering, specialised construction professions and financial services, which are estimated to account for 36 percent of all postings (European Parliament 2016).

With the increase in the number of postings, there has also been a growing interest in the academic and grey literature on the phenomenon, which is associated with the processes of work fragmentation, deregulation of labour and the transformation of the structure of employment in favour of flexibilization, outsourcing, subcontracting, and casualization that have been increasing in recent decades (Harvey 2003; Lillie 2012; Perocco 2017). As a result, the literature has focused on the impact of multi-level regulation on the employment relations and working conditions of posted workers (e.g. Caro et al. 2015; Cremers 2011; Lillie 2012; Wagner 2015; Wagner, Berntsen 2016). Their findings suggest that as part of the outsourcing practices, posting occurs at the very end of the subcontracting chain, where workers are most vulnerable. The literature that focuses on occupational safety and health (OSH) also indicates that the longer the supply chain, the more exposed workers are to $\mathrm{OSH}$ risks, particularly at the level of small and medium-sized enterprises (Cox et al. 2014; Lingard 2013; Wadsworth, Walters 2018).

This article provides a review of the existing literature on posting and occupational safety and health, which include academic articles, monographs, reports and policy briefs on the topic of posting of workers and occupational health and safety. The review revealed that there are two separate strands of literature covering the 
topic of interest: a growing one on posting and an extensive one on occupational safety and health from the perspective of various disciplines. There is, however, a gap in both literatures on the occupational health and safety of posted workers. The two strands do not intersect, with few exceptions, such as the project 'Occupational Safety and Health of Posted Workers: Depicting the existing and future challenges in assuring decent working conditions and wellbeing of workers in hazardous sectors (POOSH)' funded by the European Commission's EaSI programme, which focuses, as the name suggests, on the occupational safety and health (OSH) of posted workers in the European Union. The current review was also conducted under the auspices of this project.

The article is structured as follows: after the introduction, the European regulation on the posting of workers is presented, followed by the OSH regulatory framework. The general OSH risk factors as identified in the literature are then discussed. In the next two sections, the OSH vulnerabilities of migrant workers and of posted workers are discussed in more detail. The article closes with a few remarks on the future research agenda on posting and occupational health and safety.

\section{EUROPEAN REGULATION ON THE POSTING OF WORKERS}

The Posting of Workers Directive (96/71/EC) was adopted in 1996 after a long debate on the free movement of labour within the single market. The idea behind it was to regulate transnational labour mobility within the European Union. In principle, posted workers are part of the core workforce in the country of work/residence and are sent to another EU country to perform a task for a defined temporary period of time. From this perspective, workers are moving as services, not labour. The difference between the movement of posted workers as services rather than as people lies in the workers' restricted access to the local labour market and social rights (Wagner, Berntsen 2016).

The PWD has attracted a lot of attention since the beginning, with critics highlighting the threat of unfair competition between local and posted workers and the elevated risk of social dumping in cases where some workers are posted from countries with significant cost differentials, such as workers from Eastern or Southern Europe (Cremers 2011). Concerns about the implementation of the Directive have been addressed in two ways: through numerous rulings of the Court of Justice of the European Union, and through the passing of an Enforcement Directive in 2014 (2014/67/EU) for the enforcement of Directive 96/71/EC. In most of their decisions, such as the Laval Quartet, the Court has supported the idea that free movement of services, freedom of establishment, and free competition within the European common market prevail over equality of social rights and treatment (Dølvik, Visser 2009). The Court has interpreted the minimum protection stipulated in the PWD as a ceiling to the rights of posted workers, allowing for differences in terms and conditions 
between posted workers and local workers, thus putting posted workers in a more vulnerable position than locally-hired workers (Barnard 2009; Kilpatrick 2009; Sack 2012). The Enforcement Directive tried to address some of the concerns about social dumping through a set of measures and control mechanisms to guarantee genuine posting and increase access to information. However, many issues raised earlier remain unresolved, and social partners and industrial relations scholars have argued that the Enforcement Directive has not fulfilled its objective (ETUC 2014; Cremers 2016). As the pressure to revise the Directive has intensified in recent years, the European Council agreed to revise the PWD in October 2017 (European Council 2017), and by March 2018 a package agreement based on the principle of equal pay for equal work at the same workplace was proposed by the trialogue representatives of the European Parliament, the Council and the Commission (European Commission, 1 March 2018).

\section{OSH REGULATORY FRAMEWORK}

Occupational health and safety covers all aspects of health and safety in the workplace with a strong focus on primary prevention of hazards. There are two main sets of determinants of occupational safety and health and its regulatory framework. The first set includes risk factors at the workplace leading to cancers, accidents, musculoskeletal diseases, respiratory diseases, hearing loss, circulatory diseases, stress related disorders, communicable diseases and others. The second is related to employment and working conditions in the formal or informal economy such as working hours, salary, workplace policies concerning maternity leave, health promotion and protection provisions etc. (WHO 2017).

$\mathrm{OSH}$ is regulated at different levels. Internationally, WHO and ILO have paid particular attention to occupational health and safety. In 2007, WHO endorsed its Global Plan of Action on Workers' Health (2008-2017), which recognised the need to adopt new forms of prevention and protection in accordance with the changes in the world of work, and to expand access to OSH for vulnerable groups, including migrants. The Global Plan also underlines worker mobility and the need for improved cooperation across countries: "to encourage the development of effective mechanisms for collaboration and cooperation between developed and developing countries at regional, subregional and country levels in implementing the global plan of action on workers' health, including health needs of migrant workers."

ILO, on the other hand, has more than forty instruments on occupational health and safety, from the general provisions, to protection against specific risks, to specific branches of activity, as well as ILO's Codes of Practice (ILO 2018). In 2003, ILO also adopted a Global Strategy on Occupational Safety and Health, which, like WHO's Global Plan, highlighted the strengthening of the prevention mechanisms, inspections and education, along with the expansion of access for vulnerable groups such 
as migrants (p. 10). In 2016, ILO also published a paper titled Promoting Fair Migration: General Survey concerning the migrant workers instruments, which included a Report of the Committee of Experts on the Application of Conventions and Recommendations. While the report covers all aspects of labour migration, it also discusses the implications of labour migration on migrants' occupational safety and health. The Committee confirmed that migrant workers are more vulnerable to industrial accidents, in particular seasonal workers, who are placed in high-risk, hazardous, low-paid jobs with insufficient supervision (ILO 2016: 126). Therefore, training and other preparatory measures are again recommended for migrants in a language they understand:

The Committee reiterates the importance of taking the appropriate measures to prevent any special health risks to which migrant workers may be exposed, in particular those employed in hazardous occupations such as agriculture, construction, mining and fishing, manufacturing, and domestic work. Member States are therefore urged to make every effort to ensure that migrant workers receive training and instruction in occupational safety and health in connection with their practical training or other work preparation, where possible in a language they understand. (Recommendation No. 151, paras 20 and 21)

At the beginning of 2018, a new International Standard for occupational health and safety (ISO 45001: 2018) was published. ISO 45001 provides a set of processes for improving work safety in global supply chains, which is expected to reduce workplace injuries and illnesses around the world (Gasiorowski Denis 2018).

In the European Union, health and safety is part of the Treaty on the Functioning of the European Union. Article 153, in particular, gives the EU the authority to adopt directives in the field of safety and health at work. So far, the following OSH legislation has been adopted:

- The OSH Framework Directive

- Workplaces, equipment, signs, personal protective equipment

- Exposure to chemical agents and chemical safety

- Exposure to physical hazards

- Exposure to biological agents

- Provisions on workload, ergonomic and psychosocial risks

- Sector specific and worker related provisions

The EU directives outline the necessity of preventative measures, as well as training, education, and appropriate protection in terms of occupational health and safety. $\mathrm{OSH}$ is considered one of the EU policies that has seen substantial transformation throughout the decades, from the technical standards of the prescriptive approach in the early days to the more current goal-oriented and social dialogue approaches (Liu, Liu 2015), although more needs to be done particularly in terms of enforcement (del Castillo 2016). 
The specificities of workers posted from one Member State to another are mentioned in the Posting of Workers Directive (96/71/EC), where Article 3, titled 'Terms and conditions of employment' mentions rest periods, holidays, health and safety and hygiene, protective measures, and equality of treatment. The Enforcement Directive (2014/67/EU) readdresses the issue in terms of accessible provision of information by taking into account the transnational and therefore multi-lingual composition of the workplaces with posted workers (Article 5(2)(c)):

c) make the information available to workers and service providers free of charge in the official language(s) of the host Member State and in the most relevant languages taking into account demands in its labour market, the choice being left to the host Member State. That information shall be made available if possible in summarised leaflet form indicating the main labour conditions applicable, including the description of the procedures to lodge complaints and upon requests in formats accessible to persons with disabilities; further detailed information on the labour and social conditions applicable to posted workers, including occupational health and safety, shall be made easily available and free of charge.

Nonetheless, implementation occurs predominantly at the national level, where national health and safety systems are in place with all the necessary mechanisms for enforcement. A national OSH system comprises 'all the infrastructures, mechanisms and specialized human resources required to translate the principles and goals defined by the national policy into the practical implementation of national OSH programmes' (Alli 2008: 37). It is the result of a national OSH programme, and should constantly reflect the socio-economic and technological changes on working conditions and environment. However, this is not necessarily an easy task. National OSH structures are complex and embedded in the history of the institutional development of the individual countries. The coordination of the regulations at the different levels and the necessary (re)structuring for their implementation can be difficult in light of resistance to adjusting to a multi-lingual labour market, for example, either due to a lack of awareness of the scale of the change in the composition of the labour force or a lack of willingness to do so.

\section{OSH RISK FACTORS}

The topic of OSH is covered by a number of disciplines and often from a multi-disciplinary approach. The review findings indicate that health and safety in the workplace is dependent on several factors, such as the structures, procedures, training, artefacts, and actors involved in the process of monitoring OSH practises, as well as the workers themselves. The structures necessary to protect workers and prevent OSH risks are outlined at EU level but are detailed in the national legislation. 
Management should ensure that they are in place and fully functioning in order for the OSH system to be effective. The structures should be designed both to prevent accidents and protect workers. In order for them to work, procedures should be laid down carefully and clearly for all actors involved, and safety representatives should be provided on site. At the same time, there is a need for appropriate training in terms of operating machinery, as well as safety measures in general. Training, therefore, should be available and accessible to all. Furthermore, protective clothing and equipment are equally important. Finally, in order for all structures, procedures and training to be effective, it is essential that all actors involved are seriously committed to OSH (Guldenmund 2000; Sawacha et al. 1999).

Previous studies have found that if management is committed to OSH at all levels, the rest of the workforce is more likely to follow their example, making them the most influential factor for success (Aksorn, Hadikusumo 2008). According to Aksorn and Hadikusumo (2008), who studied the factors critical for the success of safety programmes in construction projects, management commitment includes management support, teamwork, and clear and realistic goals. In their view, the successful implementation of health and safety is guaranteed not only by providing for occupational health and safety in terms of equipment, training, and monitoring, but also by leading by example, arguing that if the management shows that they are serious about health and safety at all levels, the workforce will follow their lead.

Both grey literature and academic literature indicate that changes in the nature of work affect OSH practices. Globalisation, work fragmentation and outsourcing have brought about multiemployer workplaces with long supply chains, which present challenges for OSH (Cox et al. 2014) and elevated risks of injuries and fatal accidents (Nenonen 2011), as companies operating at different levels might apply different OSH standards. This is particularly risky for the most precarious workers, who are often located at the end of the subcontracting chain where the tension between safety and production efficiency is higher (Lingard 2013). Fragmentation and the resulting long supply chain also create workplaces with diverse working cultures, which can lead to miscommunication and conflicting interests, hence working against effective OSH management (Swuste et al. 2012). Manu et al. (2009) argue that some of the smaller subcontractors also often lack the adequate resources and the knowledge to abide by the OSH regulations. EU-OSHA European Survey of Enterprises on New and Emerging Risks (ESENER) data confirm that the challenges in handling OSH become more significant as the enterprises gets smaller (EU-OSHA n.d.; Wadsworth, Walters 2018). Additionally, lack of economic and reward factors, disorganisation, inadequate regulatory controls and organizing challenges are also visible at the end of subcontracting chain, all of which have negative implications for OSH (Mayhew et al. 1997).

The literature suggests that the challenges subcontracting poses for OSH could be addressed by strengthening the organization, which, in turn, can be achieved by having the main contractors engage in integrating $\mathrm{OSH}$ at all levels of production 
(Lingard 2013), as well as by minimizing the layers of subcontracting, working regularly with the same subcontractors, implementing reward schemes throughout the subcontracting chain, and appointing full-time OSH stewards with no other responsibilities on site (Manu et al. 2013).

The public health research literature has provided some highly relevant insights into how employment influences public health. In particular, Benach et al. (2014), identify precarious employment as an emerging social determinant of health, which according to a more recent publication by the same group of authors remains under-researched (Benach et al. 2016). These authors appeal for better definitions used in the research about health, and the inclusion of multidimensional constructs which are necessary not only to identify the pathways and mechanisms by which precarious employment affects health, but also in order to use them to build stronger information systems and better tools for the design, implementation and evaluation of the relevant policies. In their own research, they define precarious employment as: "a multi-dimensional construct encompassing dimensions of employment insecurity, individualized bargaining relations between workers and employers, low wages and economic deprivation, limited workplace rights and social protection, and powerlessness to exercise legally granted workplace rights" (ibid.). The same authors highlight the importance of comparative research as a way to "capture the diversity of welfare and labour market regimes that exist within and between countries, as well as the links between employment conditions, health outcomes and other working and social conditions" (ibid.).

\section{THE OSH VULNERABILITIES OF MIGRANT WORKERS}

Workplaces have become increasingly transnational, as workers from within the EU and third country nationals are migrating for work, which makes migration another important social factor that influences occupational health and safety (EU-OSHA 2007; Benach et al. 2010; Sargeant, Tucker 2009). Studies indicate that there is a higher incidence of workplace related accidents and fatalities among migrant workers as compared to local workers (e.g. Schenker 2010). Both the grey and academic literature underline the fact that most migrants find themselves in a segmented labour market, operating in physically demanding and highly hazardous jobs in dangerous industries, often under poor working conditions, with elevated precarity, and sometimes semi- or completely informal (EU-OSHA 2007; Benach et al. 2010; Schenker 2010). They are often exploited and abused, while also experiencing discrimination and/or bullying, social exclusion, lack of (appropriate) training on health and safety, fear of reprisal were they to demand better working conditions, incomplete systems of OSH monitoring, and lack of access to care and compensation in case of occupational injury. 
A major contribution in analysing the OSH of migrant workers was made by Sargeant and Tucker (2009), who propose a layered framework to assess the OSH vulnerabilities of migrant workers. They define migrant workers as workers without permanent status in the receiving countries, which is applicable to a variety of immigrants, such as recent, temporary, seasonal and posted migrant workers. The definition is important because it implies that permanent residents, albeit immigrants, have a wider knowledge of and access to local OSH practices, entitlements, and protection. Migrants, on the other hand, are exposed to a multi-layered vulnerability that manifests itself in different forms, depending on a set of factors. In the first layer of vulnerability, according to Sargeant and Tucker (2009) are the migration factors, such as the conditions of the recruitment and the migration status of the worker. If the conditions of recruitment are solid, i.e., regular contracts according to local national laws and/or collective agreements in place, migrant workers are more protected. Similarly, if the migrants have a regular residence and/or work permit, preferably permanent or long-term, as opposed to any form of irregular stay, they will be better protected. However, if employment is precarious, informal or semi-informal, they will be more vulnerable to OSH risks. In combination, the more insecure the migration status and the more precarious the employment, the more exposed the migrant workers are to OSH risks, with irregular migrants operating in the informal economy as the most vulnerable of all (cf. Woolfson et al. 2014).

The characteristics of the migrants themselves, namely the socio-economic conditions in the home country, education and skill levels, and language skills, are the second layer of vulnerability (Sargeant, Tucker 2009). Poor socio-economic conditions at home make migrant workers more willing to consent to poor working conditions as a means to remain in the receiving country and generate income for themselves and their families back home. As with workers in general, the level of education and skills are an important factor in terms of the training of the workers in a particular trade/profession and their ability to prevent OSH risks. Untrained and unskilled workers would be most vulnerable to OSH risks compared to others.

Sargeant and Tucker (2009) state that migrant characteristics include language skills. This would facilitate their ability to follow OSH procedure or guidelines, read signs and other OSH instructions, attend training courses etc. Lack of knowledge of the local language along with lack of access to OSH material in their native language make migrant workers more vulnerable to OSH risks. The importance of language skills as a means to receive and convey information is confirmed in the Enforcement Directive discussed above and supported by empirical evidence in other studies on the health and safety of migrants (Alli 2008; Bust et al. 2008; Tutt et al. 2011; Tutt et al. 2013). Tutt et al. (2011) highlight the importance of multilateral channels of communication between workers and management and among workers of different language backgrounds in transnational and multiemployer workplaces, which have become common in construction. For them, language facilitation, including translation and interpretation from the induction phase throughout the implementation of 
the project should coincide with language training in the local tongue. Along with precarious employment, linguistic and cultural barriers can be an additional factor to the occupational health inequalities migrant workers face.

However, language is not the only distinguishable difference between migrant and local workers. Previous research indicates that there are also differences in cultures of health and safety, which can be identified at the national level as well as at the industry level (Guldenmund 2000). In transnational workplaces, these differences in $\mathrm{OSH}$ cultures might become more visible and make some workers more vulnerable to $\mathrm{OSH}$ risks compared to others. That is not to say that some nationalities are more careless than others, but that perceptions, procedures, and communications on safety might vary, and that linguistic facilitation suggested in the previous paragraph should be informed by an awareness of cultural differences that are manifested through practices of cultural sensibilities, interpretations, and adjustments, in order to prevent risks and provide equal protection for all workers. Awareness of difference also means that prejudice and discrimination should be fought and minimized in order for OSH measures to be effective (Tutt et al. 2011).

Sargeant and Tucker place the receiving country conditions in a third layer of vulnerability, specifically the characteristics of the employment sector, access to collective representation, access to regulatory protection, and specific problems of social exclusion/social isolation. Some sectors and workplaces are more hazardous than others; therefore, if migrant workers are concentrated in these kinds of jobs, their OSH vulnerabilities are higher. Likewise, the type of employment also affects their level of vulnerability, with informal and precarious workers being the most vulnerable of all. Access to collective representation is also fundamental considering that most worker organizations have taken over monitoring OSH practices in the workplace, as well as providing representation to defend their rights in case of injury. Furthermore, it is not enough for a regulatory protection system to be in place, migrant workers have to have access to it in order not to be exposed to OSH risks. And finally, social exclusion and isolation might augment stress and other mental conditions while making protection and services inaccessible, or at least less accessible compared to their fellow workers. Under these circumstances, migrant workers would become even more vulnerable.

\section{THE OSH VULNERABILITIES OF POSTED WORKERS}

In the literature, posted workers are often mentioned as a vulnerable group exposed to higher OSH risks compared to locally hired workers because of the differences in their terms and conditions. In some cases, this is the result of irregular employment practices which leave them outside the purview of the OSH regulations and monitoring mechanisms. In other cases, this is due to social factors like precarious work and more specifically the migrant factors intertwined with precarious employment 
conditions that lead to elevated OSH risks. During the review, we did not find any published study that focuses on the occupational health and safety of posted workers. At the time of writing this article, the POOSH project mentioned above is conducting fieldwork in nine EU countries and provides some empirical data on the $\mathrm{OSH}$ of posted workers across Europe. Although there is currently no publication that focuses on the occupational safety and health of posted workers, the literature identifies several factors that might increase their OSH vulnerability.

The first set of factors is related to the terms of their employment. The cost differentials between sending and receiving countries make posting sometimes a cheaper option for employers, which might lead to some form of social dumping (Cremers 2011). Employers try to take advantage of the differences between national systems and exploit the grey areas among national and transnational regulations when posting workers. Through regulatory evasion, arbitrage and conformance, they either ignore the rules or choose to apply the ones that benefit them the most (Berntsen, Lillie 2015). While not all posting leads to social dumping, several studies indicate that posted workers, in particular in low-pay and low-skill jobs, are often paid either less or the same but then subjected to charges for various expenses such as travel, accommodation, or administrative fees, which are then subtracted from their salaries (Cremers 2011; Cremers et al. 2007; Cremers 2016; Kall, Lillie 2017; Lillie, Wagner 2015). Worker compliance with these practices is common among those with insecure employment who are highly dependent on their employers (Alberti, Danaj 2017). These practices as well as fraudulent ones such as 'fake posting', letterbox companies, and bogus self-employment, increase the OSH vulnerability of posted workers.

The second set of factors relates to their working and living conditions. Work intensification is common among posted workers, who often work extended hours, six or seven days a week (Alberti, Danaj 2017; Wagner 2017). As part of the subcontracting chain, posted workers are mostly employed by small and medium-sized companies, which, as already mentioned, are more likely not to abide by OSH regulations (EU-OSHA n.d.; Wadsworth, Walters 2018), particularly when the workforce is migrant (EU-OSHA 2007). Previous research has also found that accommodation arrangements for posted workers can frequently be poor, crowded, and sometimes isolated from the local community (Caro et al. 2015; Fitzgerald 2010). These working and living conditions in combination with language and cultural barriers expose posted workers to high risks in terms of health and safety and put them in more vulnerable positions than the rest of the workforce (Caro et al. 2015; Rogelja et al. 2016).

The third set of factors relates to social protection. Despite the fact that the process of portability of social security in the EU is clear in theory, in practice it is quite complex and uncertain for both public authorities and workers. The barriers are created by the complex national regulatory frameworks and institutional settings and procedures. The inequalities in access are higher for those with lesser means, poor language skills, and in employment with cross-border mobility (Carmel et al. 2016; Scheibelhofer et al. 2016), such as posted workers. These factors become crucial in 
cases of work-related injury, illness, and death, which might considerably limit access to health and care benefits for posted workers.

The fourth set of factors relates to worker representation. National trade unions have addressed the issue of posting in an effort to prevent social dumping, often by trying to ensure that posted workers are provided the same terms and conditions as local workers. In some cases, they have demanded the application of the terms of collective agreements, which have been rejected by most CJEU decisions. At the same time, unions have tried to provide support and organize posted workers. However, because of the high level of subcontracting, unions cannot always access workers immediately. The temporary and hyper-mobile nature of their employment have also been major challenges for national unions, which even when successful at a certain point in time have not been able to sustain their success long term, as workers move across borders and countries constantly (Berntsen 2015; Danaj, Sippola 2015; Lillie, Sippola 2011).

The situation is particularly difficult for third country nationals posted via a member state, such as Bosnians posted from Slovenia. Posted TCN workers with work-related injuries often face dire situations. There have been several cases of permanently injured workers being completely abandoned after initially being returned to the country where they were posted from and then to their country of origin (Lukić 2017). There is no support for these workers, apart from a few NGOs or the Counselling Office, which try to provide information and assist these workers in order for them to receive some financial and health care support (Vah Jevšnik 2018).

\section{POSTING AND OSH: A RESEARCH AGENDA}

The literature review on posting and occupational safety and health revealed that there is growing literature tackling the complexities of posting and there is extensive literature addressing occupational safety and health in various disciplines. Although the vulnerabilities of posted workers are discussed in the former, and the overall risk factors, including those relevant to migrant workers, are discussed in the latter, the two strands of literature barely intersect. There is therefore an immediate need to bridge the gap by studying the occupational safety and health of posted workers throughout the European Union.

Furthermore, although there is empirical evidence that speaks to the influence of the migration processes on the health of migrants, analytical and policy-oriented research is still limited in scale and scope (Benach et al. 2010). The literature on safety and health has already identified a series of social factors that influence the $\mathrm{OSH}$ of workers, such as subcontracting and precarity, and they have also underlined the need for further research into how the fragmentation of labour affects OSH and identifying the ways in which OSH risks can be minimized (Benach et al. 2014; 2016). The literature on the $\mathrm{OSH}$ of migrant workers has also identified a series of factors 
that stem from the fact that they are also migrants, and discussed the implications of cross-border mobility on their occupational safety and health. The layers of vulnerability of the migrant workers framework (Sargeant, Tucker 2009) would then be applicable to the study of posted workers, as a particular kind of migrant workers. The differentiating factors between posted workers and other types of migrant workers, however, should complement any analytical framework and study in order to be able to capture the complexities of their situation and provide a more detailed account of their OSH vulnerabilities and experiences.

\section{REFERENCES}

Aksorn, Thanet, Hadikusumo, B. H. W. (2008). Critical Success Factors Influencing Safety Program Performance in Thai Construction Projects. Safety Science 46/4, 709-727.

Alberti, Gabriella, Danaj, Sonila (2017). Posting and Agency Work in British Construction and Hospitality: The Role of Regulation in Differentiating the Experiences of Migrants. The International Journal of Human Resource Management 28/21, 3065-3088.

Alli, Benjamin O. (2008). Fundamental Principles of Occupational Health and Safety. International Labour Organization (ILO).

Barnard, Catherine (2009). The UK and Posted Workers: The Effect of Commission v Luxembourg on the Territorial Application of British Labour Law: Case c-319/06 Commission v Luxembourg, Judgment 19 June 2008. Industrial Law Journal 38/1, 122-132.

Benach, Joan, Muntaner, Carles, Chung, Haejoo, Benavides, Fernando G. (2010). Immigration, Employment Relations, and Health: Developing a Research Agenda. American Journal of Industrial Medicine 53/4, 338-343.

Benach, Joan, Vives, Alejandra, Amable, Marcelo, Vanroelen, Christophe, Tarafa, Gemma, Muntaner, Carles (2014). Precarious Employment: Understanding an Emerging Social Determinant of Health. Annual Review of Public Health 35, 229-253.

Benach, Joan, Vives, Alejandra, Tarafa, Gemma, Delclos, Carlos, Muntaner, Carles (2016). What Should we Know about Precarious Employment and Health in 2025? Framing the Agenda for the next Decade of Research. International Journal of Epidemiology 45/1, 232-238.

Bust, Philip D., Gibb, Alistair GF, Pink, Sarah (2008). Managing Construction Health and Safety: Migrant Workers and Communicating Safety Messages. Safety Science 46/4, 585-602.

Carmel Emma, Sojka, Bozena, Papiez, Kinga (2016). A Comparative Analysis of the Portability of Social Security Rights within the European Union. WFS Policy Brief $\neq 1 / 2016$, https://welfarestatefutures.files.wordpress.com/2016/04/transwel_ polb_1-3_2016.pdf (6. 4. 2018). 
Caro, Erka, Berntsen, Lisa, Lillie, Nathan, Wagner, Ines (2015). Posted Migration and Segregation in the European Construction Sector. Journal of Ethnic and Migration Studies 41/10, 1600-1620.

Cox, Annette, Fletcher, Luke, Rhisiart, M. (2014). Scoping Study for a Foresight on New and Emerging Occupational Safety and Health (OSH) Risks and Challenges: European Risk Observatory. Publications Office of the European Union.

Cremers, Jan (2016). Economic Freedoms and Labour Standards in the European Union. Transfer: European Review of Labour and Research 22/2, 149-162.

Cremers, Jan (2011). In Search of Cheap Labour in Europe: Working and living Conditions of Posted Workers. Brussels: CLR.

Cremers, Jan, Dølvik, Jon Erik, Bosch, Gerhard (2007). Posting of Workers in the Single Market: Attempts to Prevent Social Dumping and Regime Competition in the EU. Industrial Relations Journal 38/6, 524-541.

Del Castillo, Aida Ponce (2016). Occupational Safety and Health in the EU: Back to Basics. Social Policy in the European Union: State of Play (eds. Bart Vanhercke, David Natali, Denis Bouget). Seventeenth Annual Edition. Brussels: ETUI.

Dølvik, Jon Erik, Visser, Jelle (2009). Free Movement, Equal Treatment and Workers' Rights: Can the European Union Solve its Trilemma of Fundamental Principles? Industrial Relations Journal 40/6, 491-509.

ETUC (2014). Barroso and MEPs Fail to Sort out the Rights of 'Posted' workers. April 16, http://www.etuc.org/press/barroso-and-meps-fail-sort-out-rights-postedworkers\#.VPndRuHIXIV (20. 4. 2015).

European Commission (2018). Joint Statement on the Revision of the Posting of Workers Directive. News. March, http://ec.europa.eu/social/main.jsp?langld=en\&catld $=89 \&$ newsld $=9062 \&$ furtherNews=yes $(13.4 .2018)$

European Council (2017). Posting of Workers: Council Reaches Agreement. Press Release. 23 October, http://www.consilium.europa.eu/en/press/press-releases/2017/10/23/epsco-posting-of-workers (13.4. 2018).

European Parliament. (2016). Directorate General for Internal Policies Policy Department: Economic and Scientific Policy Posting of Workers Directive - Current Situation and Challenges.

EU-OSHA (2007). Literature Study on Migrant Workers (EU-OSHA, Bilbao), https://osha. europa.eu/en/publications/literature_reviews/migrant_workers (17. 4. 2018).

EU-OSHA (nd). Safety and Health in Micro and Small Enterprises, https://osha.europa. eu/en/themes/safety-and-health-micro-and-small-enterprises (17. 4. 2018).

Fitzgerald, Ian (2010). Improving Best Practices on the Working and Living Conditions of Posted Workers: Country report UK.

Gasiorowski Denis, Elizabeth (2018). ISO 45001 is now Published, https://www.iso.org/ news/ref2272.html (17. 4. 2018).

Guldenmund, Frank W. (2000). The Nature of Safety Culture: A Review of Theory and Research. Safety Science 34/1, 215-257. 
Harvey, Mark (2003). Privatisation, Fragmentation, and Inflexible Flexibilization in the UK Construction Industry'. Building Chaos: An International Comparison of Deregulation in the Construction Industry (eds. Gerhard Bosch, Peter Philips). Routledge, 188-209.

ILO (2018). International Labour Standards on Occupational Safety and Health, http:// www.ilo.org/global/standards/subjects-covered-by-international-labour-standards/occupational-safety-and-health/lang--en/index.htm (17. 4. 2018).

ILO (2016). Promoting fair Migration: General Survey Concerning the Migrant Workers Instruments. Geneva: ILO, http://www.ilo.org/wcmsp5/groups/public/---ed_ norm/---relconf/documents/meetingdocument/wcms_453898.pdf (17. 4. 2018).

ILO. (2004). Global Strategy on Occupational Safety and Health. Geneva: ILO, http:// www.ilo.org/wcmsp5/groups/public/---ed_protect/---protrav/---safework/documents/policy/wcms_107535.pdf (17. 4. 2018).

Kall, Kairit, Lillie, Nathan (2017). Protection of Posted Workers in the European Union: Findings and Policy Recommendations Based on Existing Research. PROMO briefing paper, http://www.solidar.org/system/downloads/attachments/000/000/700/original/2017_09_26_PROMO_Briefing_Paper_KKall_final. pdf?1506505471 (28. 2. 2018).

Kilpatrick, Claire (2009). Laval's Regulatory Conundrum: Collective Standard-Setting and the Court's New Approach to Posted Workers. European Law Review 34/6, 844-865.

Kitay, Jim, Callus, Ron (1998). The Role and Challenge of Case Study Design in Industrial Relations Research. Researching the World of Work: Strategies and Methods in Studying Industrial Relations (eds. Keith Whitfield, George Strauss). Cornell University Press.

Lillie, Nathan (2012). Subcontracting, Posted Migrants and Labour Market Segmentation in Finland. British Journal of Industrial Relations 50/1, 148-167.

Lillie, Nathan, Wagner, Ines (2015). Subcontracting, Insecurity and Posted Eork: Evidence from Construction, Meat Processing, and Ship Building. The Outsourcing Challenge: Organizing Workers Across Fragmented Production Networks (ed. Jan Drahokoupil). Brussels: European Trade Union Institute, 157-174.

Lingard, Helen (2013). Occupational Health and Safety in the Construction Industry. Construction Management and Economics 31/6, 505-514.

Liu, Kai, Liu, Wen (2015). The Development of EU Law in the Field of Occupational Health and Safety: A New Way of Thinking. Management and Labour Studies 40/3-4), 207-238.

Lukić, Goran (2017). Working Conditions of Posted Workers - What About OSH? POOSH Transnational Conference - Employment/Working Conditions, Occupational Safety and Health of Posted Workers, 15 February, Ljubljana, Slovenia.

Manu, Patrick, Ankrah, Nii, Proverbs, David, Suresh, Subashini (2013). Mitigating the Health and Safety Influence of Subcontracting in Construction: The Approach of Main Contractors. International Journal of Project Management 31/7, 1017-1026. 
Manu, Patrick, Ankrah, Nii, Proverbs, David, Suresh, Subashini, Callaghan, Eddie (2009). Subcontracting Versus Health and Safety: An Inverse Relationship. Proceedings of CIB W099 2009 Conference, 21-23 October (eds. H. Lingard, T. Cooke, M. Turner). Melbourne, Australia: RMIT.

Mayhew, Claire, Quintan, Michael, Ferris, Rande (1997). The Effects of Subcontracting/Outsourcing on Occupational Health and Safety: Survey Evidence from Four Australian Industries. Safety Science 25/1, 163-178.

Nenonen, Sanna (2011). Fatal Workplace Accidents in Outsourced Operations in the Manufacturing Industry. Safety Science 49/10, 1394-1403.

Pacolet, Jozef, De Wispelaere, Frederic (2016). Posting of Workers: Report on A1 Portable Documents Issued in 2015 (Rep.). Brussels: Network Statistics FMSSFE, European Commission.

Perocco, Fabio (2017). Precarización del trabajo y nuevas desigualdades: El papel de la inmigración. REMHU-Revista Interdisciplinar da Mobilidade Humana 25/49.

Rogelja, Nataša, Toplak, Kristina, Vah Jevšnik, Mojca, Mlekuž, Jernej (2016). Napotitve delavcev iz Slovenije: Nekatere specifike in problemi [The Posting of Workers from Slovenia: Some Particularities and Problems]. Dve domovini / Two Homelands 44, 125-137.

Sack, Detlef (2012). Europeanization through Law, Compliance, and Party Differences - the ECJ's 'Rüffert'Judgment (C-346/06) and Amendments to Public Procurement Laws in German Federal states. Journal of European Integration 34/3, 241-260.

Sargeant, Malcolm, Tucker, Eric (2009). Layers of Vulnerability in Occupational Safety and Health for Migrant Workers: Case Studies from Canada and the UK. Policy and Practice in Health and Safety $7 / 2,51-73$.

Sawacha, Edwin, Naoum, Shamil, Fong, Daniel (1999). Factors Affecting Safety Performance on Construction Sites. International Journal of Project Management 17/5, 309-315.

Scheibelhofer, Elisabeth, Balogh, Eszter, Regös, Nora (2016). A Comparative Analysis of the Portability of Social Security Rights within the European Union. Hungary-Austria case study. WFS Policy Brief $\neq 4 / 2016$, https://welfarestatefutures.files. wordpress.com/2017/11/transwel_polb_4-3_2016-revised.pdf (6. 4. 2018).

Schenker, Marc B. (2010). A Global Perspective of Migration and Occupational Health. American Journal of Industrial Medicine 53/4, 329-337.

Swuste, Paul, Frijters, Andri, Guldenmund, Frank (2012). Is it Possible to Influence Safety in the Building Sector? A Literature Review Extending from 1980 until the Present. Safety Science 50/5, 1333-1343.

Tutt, Dylan, Dainty, Andy RJ, Gibb, Alistair, Pink, Sarah (2011). Migrant Construction Workers and Health \& Safety Communication: Construction Industry Training Board (CITB)-Construction Skills. Bircham Newton, King's Lynn, Norfolk, UK.

Tutt, Dylan, Pink, Sarah, Dainty, Andy RJ, Gibb, Alistair (2013). 'In the Air' and Below the Horizon: Migrant Workers in UK Construction and the Practice-Based Nature 
of Learning and Communicating OHS. Construction Management and Economics 31/6, 515-527.

Vah Jevšnik, Mojca (2018). POOSH Country Report in Slovenia. Unpublished manuscript.

Wadsworth, Emma, Walters, David (2018). Management of Occupational Health and Safety in European Workplaces - Evidence from the Second European Survey of Enterprises on New and Emerging Risks (ESENER-2). European Risk Observatory Report. Luxembourg: Publications Office of the European Union, https://osha. europa.eu/en/tools-and-publications/publications/management-occupational-health-and-safety-european-workplaces (17. 4. 2018).

Wagner, Ines (2017). Changing Regulations, Changing Practices? The Case of the German Meat Industry. Report for the PROMO project, http://www.solidar.org/system/downloads/attachments/000/000/702/original/2017_09_28_PROMO_briefing_paper_Wagner.pdf?1506505471 (28. 2. 2018)

Wagner, Ines (2015). Rule Enactment in a Pan-European Labour Market: Transnational Posted Work in the German Construction Sector. British Journal of Industrial Relations 53/4, 692-710.

Wagner, Ines, Berntsen, Lisa (2016). Restricted Rights: Obstacles in Enforcing the Labour Rights of Mobile EU Workers in the German and Dutch Construction Sector. Transfer: European Review of Labour and Research 22/2, 193-206.

Woolfson, Charles, Fudge, Judy, Thörnqvist, Christer (2014). Migrant Precarity and Future Challenges to Labour Standards in Sweden. Economic and Industrial Democracy 35/4, 695-715.

World Health Organization (2017). Health Topics, http://www.who.int/topics/occupational_health/en/ (17.9. 2017).

World Health Organization (2007). Workers' Health: Global Plan of Action. Geneva: WHO, Sixtieth World Health Assembly. 


\section{POVZETEK}

\section{NAPOTENO DELO TER VARNOST IN ZDRAVJE PRI DELU: PREGLED LITERATURE \\ Sonila DANAJ}

Direktiva o napotitvah delavcev (96/71/EC) (PWD) iz leta 1996 je bila namenjena regulaciji začasne delovne mobilnosti na skupnem evropskem trgu. Po širitvi Evropske unije leta 2004 je naraslo število napotitev iz držav Srednje in Vzhodne Evrope z nižjim prihodkom v države z višjim prihodkom; leta 2015 je doseglo že številko 1,5 milijona. Število napotitev je sovpadlo z naraščajočim zanimanjem za obravnavani družbeni pojav. Avtorica podaja pregled obstoječe literature o napotitvah ter zdravju in varnosti pri delu, in sicer akademskih člankov, monografij, študij in uradnih poročil o napotitvah delavcev ter zdravju in varnosti pri delu. Poleg splošne direktive napotitve delavcev urejajo tudi Direktiva o uresničevanju in številne odločitve Evropskega sodišča, v katerih je VZD obravnavana na mednarodni, evropski in državni ravni. Kljub temu pa je za uresničevanje zdravja in varnosti pri delu pomembna predvsem državna raven, na kateri se razvijajo kompleksni sistemi zdravja in varnosti. Pregled je pokazal obstoj dveh ločenih segmentov literature o omenjeni tematiki: rastoče število del o napotitvah in obsežen sklop literature o zdravju in varnosti pri delu z vidika različnih disciplin. Iz pregleda literature je razvidno, da sta zdravje in varnost na delovnem mestu odvisna od številnih dejavnikov, kot so struktura podjetja, postopki, šolanje, artefakti, osebje, vključeno v proces nadzorovanja ZVD praks, pa tudi sami zaposleni. Na ZVD prav tako vplivajo spremembe v naravi dela, kot so fragmentacija dela in zunanji izvajalci; podjetja z dolgimi dobavnimi verigami, ki delujejo na različnih ravneh, lahko namreč upoštevajo drugačne ZVD standarde. Literatura o ZVD in migracijah je dragocen vir za proučevanje varnosti pri delu migrantskih delavcev (Sargeant, Tucker 2009), pri čemer so pomembni migracijski dejavniki, značilnosti migrantov in razmere $v$ deželah sprejema. Čeprav literatura o napotitvah omenja različne dejavnike, kot so pogoji zaposlovanja, delovne in bivalne razmere, socialna zaščita in zastopanost delavcev, ki lahko zvišujejo tveganje za ZVD napotenih delavcev, trenutno o tem ni nobene študije, kar pomeni, da v literaturi o varnosti in zdravju pri delu napotenih delavcev obstaja vrzel. Za študijo o napotenih delavcih kot posebni zvrsti migrantskih delavcev bi bili uporabni podatki s kazalci njihove ranljivosti. Dejavnike razlikovanja med napotenimi in drugimi migrantskimi delavci bi morale dopolnjevati analitične študije, s pomočjo katerih bi dobili celovitejšo podobo njihovega položaja in podrobnejši opis ranljivosti in tveganj, povezanih z njihovim zdravjem in varnostjo pri delu. 